\title{
Resumos / Abstracts
}

Amanda Fiorani BARRETO; Leonardo Bérenger Alves CARNEIRO BEN JONSON NO BRASIL: OS PARATEXTOS DAS TRADUÇÕES BRASILEIRAS DE VOLPONE, OU A RAPOSA (1605/1606)

Ben Jonson (1572-1637), dramaturgo e poeta inglês das eras elisabetana e jacobina e autor aclamado já a seu tempo, ainda conta com escassas traduções no Brasil, apesar de ter suas obras amplamente lidas, encenadas e traduzidas em diversas partes do mundo. Este artigo se propõe, então, a analisar os paratextos das únicas traduções publicadas para o português brasileiro de peças teatrais de Jonson a fim de pensar no porquê de o autor ter sido pouco traduzido ao longo da história editorial brasileira. Para isso, faremos uso do conceito de paratexto proposto por Gérard Genette (2009; 2010), além de discutir outras acepções do conceito e a razão pela qual decidimos utilizá-lo em nossa fundamentação teórica, levando em consideração também o contexto de produção dessas traduções. Os paratextos aqui analisados pertencem a traduções da peça Volpone, ou a Raposa (1605-06), sendo a primeira feita por Newton Belleza (1977) e a segunda por Ganymédes José (1987). Além disso, trabalharemos com uma resenha que comenta a tradução de Belleza, publicada na época em que ela foi produzida.

Palavras-chave: Estudos da Tradução; Era Jacobina; Ben Jonson; Volpone, ou A Raposa; Paratextos

BEN JONSON IN BRAZIL: THE PARATEXTS OF THE BRAZILIAN TRANSLATIONS OF VOLPONE; OR, THE FOX (1605/1606)

Ben Jonson (1572-1637), English playwright and poet from the Elizabethan and Jacobean eras and already an acclaimed author in his time, still has few translations of his work in Brazil, despite it being widely read, performed, and translated across the globe. This article aims at analysing the paratexts 
of the only published translations of plays by Ben Jonson (1572-1637) to Brazilian Portuguese to attempt to understand why there are not more translations of works by this author in Brazil. To that end, this piece will use Gérard Genette's concept of paratexts (1997; 2010), besides discussing other meanings of the term and the reason we decided to make use of this notion in our theoretical foundation. The two paratexts here analysed belong to translations of the play Volpone; or, The Fox (1605/1606), the first one produced by Newton Belleza in 1977 and the second one by Ganymédes José in 1987. Moreover, this article will also work with a review that comments on Belleza's translation, published at the time it was produced. In addition, hypothesis will be brought forward as to the reasons behind the absence of translations of works by Jonson in Brazil.

Keywords: Translation Studies; Jacobean Era; Ben Jonson; Volpone; or, The Fox; Paratexts

\section{Amarílis Lage de MACEDO}

O HOMEM QUE CALCULAVA, DE MALBA TAHAN: UMA PSEUDOTRADUÇÃO DO ÁRABE COM DIREITO A AUTOR E TRADUTOR FICTÍCIOS

Lançado em 1937, o romance $O$ homem que calculava é um verdadeiro fenômeno editorial - segue sendo reeditado no Brasil, foi traduzido para vários idiomas e já inspirou diversas pesquisas. Contudo, um aspecto do livro permanece pouco estudado: o fato de que ele é uma pseudotradução. Afinal, embora seja atribuído ao árabe Malba Tahan (e inclua até notas do tradutor), ele foi escrito por um professor brasileiro. A análise desse romance pela perspectiva dos Estudos da Tradução ilumina elementos formais e semânticos do texto, contribui para a compreensão da época em que foi produzido e evidencia como a historiografia da tradução no Brasil tem casos ricos e complexos.

Palavras-chave: Pseudotradução; Estudos Descritivos da Tradução; Malba Tahan 
THE MAN WHO COUNTED, BY MALBA TAHAN: A PSEUDOTRANSLATION WHERE BOTH AUTHOR AND TRANSLATOR ARE FICTITIOUS

The novel The man who counted (1937) is a very successful case in Brazil's literary system. The book has been translated into several languages and has already inspired a number of researchers. However, one aspect of this novel remains poorly studied: the fact that it is a pseudo-translation. The book, written by a Brazilian teacher, was presented as a translation of a fictional Arabian author named Malba Tahan and even shows translation notes. An analysis of this novel from the perspective of Translation Studies can highlight some formal and semantic elements of the text. Moreover, it helps us understand the context in which it was written and shows how the historiography of translation in Brazil includes rich and very complex cases.

Keywords: Pseudotranslation; Descriptive Translation Studies; Malba Tahan

\section{Adriana Ceschin RIECHE}

O PAPEL DA TRADUÇÃO E DOS TRADUTORES NA PRODUÇÃO DE DICIONÁRIOS BILÍNGUES NO BRASIL: UMA HISTÓRIA POR CONTAR O presente artigo investiga o papel da tradução e dos tradutores na produção de dicionários bilíngues especializados, com ênfase no par de idiomas inglêsportuguês, a partir da segunda metade do século XX no Brasil. O objetivo é dar visibilidade aos tradutores autores dos dicionários selecionados para o estudo, por meio de uma visão histórica, com base em Pym (2014), chegando aos dias atuais, na tentativa de entender qual será a participação da tradução e dos tradutores nesse processo no futuro.

Palavras-chave: História da tradução; Dicionários bilíngues; Tradução especializada

THE ROLE OF TRANSLATION AND TRANSLATORS IN THE PRODUCTION OF BILINGUAL DICTIONARIES IN BRAZIL: A STORY YET TO BE TOLD

This paper investigates the role of translation and translators in the production of specialized bilingual dictionaries, focusing on the English-Portuguese 
language pair, as of the second half of the 20th century in Brazil. The objective is to give visibility to the translators who wrote the dictionaries selected for the study, through a historical perspective, based on Pym (2014), up to the present day in an attempt to understand how translation and translators will participate in this process in the future.

Keywords: Translation History; Bilingual Dictionaries; Specialized Translation

\section{Matheus Oliveira Paiva CURI; Carolina Geaquinto PAGANINE}

UMA ANÁLISE DAS EDIÇÕES EM LÍNGUA ESPANHOLA DO ROMANCE MANUAL PRÁTICO DO ÓDIO, DE FERRÉZ

Este artigo investiga como três traduções do romance Manual prático do ódio (Objetiva, 2003), de Ferréz, foram feitas para as variedades argentina, mexicana e peninsular da língua espanhola. Analisando fatores textuais - tradução das variedades não-padrão - e fatores paratextuais (GENETTE, 2009), procurou-se compreender como os aspectos supracitados refletiriam práticas editoriais e de tradução pertencentes a cada um dos mercados onde essas traduções circularam.

Palavras-chave: Crítica de tradução; Ferréz; Literatura marginal; Variação linguística; Espanhol

\section{ANÁLISIS DE LAS EDICIONES EN LENGUA ESPAÑOLA DE LA NOVELA MANUAL PRÁTICO DO ÓDIO, DE FERRÉZ}

Este artículo investiga como se tradujo la novela Manual prático do ódio (Objetiva, 2003), de Ferréz, para las variedades argentina, mexicana y peninsular de la lengua española. A través del análisis de factores textuales - traducción de variedades no estándares - y factores paratextuales (GENETTE, 2009), se procuró comprender como los aspectos mencionados reflejarían prácticas editoriales y de traducción pertenecientes a cada uno de los mercados donde esas traducción han circulado.

Palabras-clave: Crítica de la traducción; Ferréz; Literatura marginal; Variación lingüística; Español 


\section{Anna Olga Prudente de OLIVEIRA}

DA TRADUÇÃO À CRIAÇÃO LITERÁRIA: OS CONTOS DE FADAS REESCRITOS POR ANGELA CARTER

Este artigo discute a relevância da atividade tradutória para a criação literária de Angela Carter, analisando a obra The Bloody Chamber and Other Stories (A câmara sangrenta e outras histórias), criada a partir de contos de fadas, como os do autor francês Charles Perrault. Com base no conto The Bloody Chamber (A câmara sangrenta), inspirado na história de "Barba Azul", são discutidas questões relativas ao projeto de tradução da escritora inglesa e sua (re)escrita autoral a partir de uma perspectiva feminista, sendo estabelecida uma relação inextricável entre tradução e criação literária.

Palavras-chave: Estudos Feministas de Contos de Fadas; Angela Carter; Reescrita de contos de fadas; A câmara sangrenta

\section{FROM TRANSLATION TO LITERARY OUTPUT: THE FAIRYTALES} REWRITTEN BY ANGELA CARTER

This article discusses the importance of the translation activity in Angela Carter's literary output, analysing the work The Bloody Chamber and Other Stories, which took inspiration from existing fairy tales, such as those published by the French author Charles Perrault. On the basis of the tale The Bloody Chamber, inspired by the story of "Bluebeard", the discussion addresses Carter's translation project and her (re)writing of the story from a feminist perspective, establishing an inextricable relation between translation and literary output.

Keywords: Feminist Fairy-Tale Studies; Angela Carter; Fairy tale rewritings; The Bloody Chamber

\section{Maria de Lourdes SETTE}

NEITHER AUTHOR, NOR CO-AUTHOR. TRANSLATOR

This work seeks to examine traditional views on translation and translators, which have led to the construction of a melancholic professional identity, and to reflect on their roots. The inputs used in this analysis were a body of 
literature produced during the last thirty years, above all by translation theorists, and a selection of texts written by Brazilian translators and critics of translation over a decade (the 1990s), comprising: a) the metaphors used when discussing translation and translators; $b$ ) the criticisms made to denounce the marginal status and lack of prestige of translators and translation; and c) the theoretical and conceptual proposals that were developed, based on post-structuralism, in order to revert this negative situation. An interpretative analysis was produced, influenced by translation scholars aligned with post-structuralist ideas and based on the psychoanalytic concepts of melancholy and identity.

Keywords: Translator; Identity; Postmodernity; Psychoanalysis

\section{NEM AUTOR, NEM COAUTOR. TRADUTOR}

Este trabalho aborda a visão tradicional sobre a tradução e os tradutores que levou à construção de uma identidade profissional melancólica e tem o objetivo de refletir sobre suas causas. Os dados desta pesquisa foram a literatura produzida, sobretudo nos últimos trinta anos, por teóricos da tradução e depoimentos e paratextos feitos por tradutores brasileiros e por críticos de tradução na década de 1990, mais especificamente: a) as metáforas que utilizaram para falar de tradução e de tradutor; b) as críticas que formularam às principais noções que sustentam uma representação metafórica marginalizadora e que visam a denunciar o lugar de marginalidade ou desprestígio em que o tradutor foi colocado; e c) as proposições teóricas e conceituais que desenvolveram, a partir do pós-estruturalismo, visando a reversão desse quadro negativo. Sob a influência de estudiosos da tradução que se alinham com as ideias pós-estruturalistas e, com base nos conceitos psicanalíticos de melancolia e identidade foi feita uma análise interpretativa desse material. Palavras-chave: Tradutor; Identidade; Pós-modernidade; Psicanálise 


\section{Lauro Maia AMORIM}

CAPITAL SIMBÓLICO, PÚBLICO-LEITOR E A TRADUÇÃO DE BESTSELLERS: A QUESTÃO DA REPRESENTAÇÃO DA VARIAÇÃO LINGUÍSTICA EM ANDRÓIDES SONHAM COM OVELHAS ELÉTRICAS?, DE PHILIP DICK, E EM STAR WARS: PROVAÇÃO, DE TROY DENNING

Neste artigo desenvolve-se uma reflexão em torno de duas questões de pesquisa: a) Seria possível observar, com base em análises empírico-descritivas, a existência de correlações entre os diferentes níveis de consagração, ou seja, de capital estético-simbólico, atribuídos às obras literárias e aos seus autores, e a (maior ou menor) frequência de marcas de oralidade, como forma de representação da variação linguística, nos diálogos ficcionais em obras traduzidas? b) Seria possível supor que tradutores e editores possam projetar prováveis públicos-leitores, para certas obras literárias, e que isso poderia exercer alguma influência no modo com que essas obras são traduzidas do ponto de vista da representação da variação linguística nos diálogos ficcionais? Este artigo apresenta resultados de uma pesquisa, em andamento, que busca responder a essas questões. Para tanto, este artigo analisa, de forma qualitativa e quantitativa (com o emprego do software Wordsmith Tools-versão 7), as ocorrências de marcas de oralidade diafásicas nos diálogos ficcionais de duas obras traduzidas da literatura de ficção científica às quais se atribuem níveis diferentes de capital estético-simbólico: o cult Andróides sonham com ovelhas elétricas?, de Philip K. Dick (2017), e o spin-off Star Wars: provação, de Troy Denning (2015), ambas publicadas pela editora Aleph (especializada em ficção científica), e traduzidas, respectivamente, por Ronaldo Bressane e Alexandre Mandarino.

Palavras-chave: Tradução; Capital simbólico; Best-sellers; Ficção científica; Marcas de oralidade; Público-leitor

SYMBOLIC CAPITAL, READERSHIP, AND TRANSLATION OF BESTSELLERS: THE ISSUE OF THE REPRESENTATION OF LINGUISTIC VARIATION IN ANDROIDES SONHAM COM OVELHAS ELÉTRICAS?, BY PHILIP K. DICK, AND IN STAR WARS: PROVAÇÃO, BY TROY DENNING This paper proposes a reflection based on two research questions: a) Would it be possible to observe, by resorting to an empirical-descriptive analysis, 
the existence of correlations between different levels of consecration or aesthetic-symbolic capital, ascribed to literary works and their authors, and the (greater or lesser) frequency of orality marks by way of representing linguistic variation in fictional dialogues in translated fiction? b) Could we consider that both translators and publishing editors may project likely target-audiences for certain literary works and that such projection may have any influence on the way in which these works might be translated in regard to the representation of linguistic variation in fictional dialogues? This paper presents results of an ongoing research that seeks to answer these questions by analyzing, both qualitatively and quantitatively (by means of Wordsmith Tools 7), the occurrences of orality marks (diaphasic variation) in fictional dialogues of two science fiction novels to which it has been ascribed distinct levels of aesthetic-symbolic capital: the cult fiction Andróides sonham com ovelhas elétricas?, by Philip K. Dick (2017), and the spin-off Star Wars: provação, by Troy Denning (2015), both published by Aleph in Brazil (a science fiction publisher), and translated by Ronaldo Bressane and Alexandre Mandarino, respectively.

Keywords: Translation; Symbolic capital; Best-sellers; Science fiction; Orality marks; Target-audience

\section{Elizabeth RAMOS}

\section{MUCH ADO ABOUT OBSCENITY}

The Shakespearean comedy Much Ado About Nothing (1598-9) was written at a time when the codes of rudeness, obscenity and indecency were socially less stringent. In the sixteenth century England, some tolerance prevailed towards the obscene language, here understood as the transgressing lexicon to refer to sexuality inserted by the playwright in his production by means of innuendos, metaphors, allusions and puns. Nevertheless, in the eighteenth and nineteenth centuries, with the attempts to moralize the plays for the sake of decorum and rectitude, obscenity was eliminated from the Shakespearean work, which had then become canonical. After all, it was argued that the use of lower forms of language had been due to the playwright's desire to please 
less refined audiences. If on one hand that sort of action prevented Shakespeare's work from being completely excluded from school textbooks and family shelves, on the other, it led those who translate and adapt his works to ignore expressions with which Shakespeare built his lewd comical images. This article explores the choices for adapting the lewd play with words in the BBC adaptation Much Ado About Nothing, an episode broadcasted in 2005, under Brian Percival's direction, as part of the project Shakespeare Retold. I am particularly interested in the way Percival, in his role of director, handled the lewd innuendos, metaphors, allusions and puns found in the Shakespearean text in his rereading to be viewed at spectators' homes, in many instances, in a family setting.

Keywords: Lewd language; Translation; William Shakespeare; Much Ado about Nothing

\section{MUITO BARULHO POR LASCÍVIA}

A comédia shakespeariana Muito barulho por nada (1598-9) foi escrita em uma época em que os códigos de lascívia, obscenidade e indecência eram socialmente menos rigorosos. Na Inglaterra do século XVI, prevalecia certa tolerância em relação à linguagem obscena, aqui entendida como aquela que é veiculada por meio de um léxico transgressor, para se referir à sexualidade inserida pelo dramaturgo em sua produção, por meio de insinuações, metáforas, alusões e trocadilhos. Nos séculos XVIII e XIX, no entanto, com as tentativas de moralizar as peças em nome do decoro e da boa educação, a obscenidade foi eliminada da produção shakespeariana, que então tornara-se canônica. Afinal, argumentava-se que o uso de formas inferiores de linguagem se devia ao desejo do dramaturgo de agradar a públicos menos refinados. Se por um lado esse tipo de ação impediu que a obra de Shakespeare fosse completamente excluída dos livros escolares e estantes das casas de família, por outro, levou aqueles que traduzem e adaptam suas obras a ignorar expressões com as quais Shakespeare construiu suas imagens cômicas chulas. Este artigo explora as opções de adaptação do jogo obsceno de palavras na adaptação da BBC, Much Ado About Nothing, episódio transmitido em 2005, sob a direção de Brian Percival, como parte do projeto Shakespeare Re- 
told. Estou particularmente interessada na maneira como Percival, na condição de diretor, lidou com as insinuações, metáforas, alusões e trocadilhos obscenos encontrados no texto de Shakespeare, em sua releitura feita para ser assistida no espaço doméstico, em muitos casos, um ambiente familiar. Palavras-chave: Linguagem chula; Tradução; William Shakespeare; Muito barulho por nada

\section{Jonathan EVANS}

\section{A TRADUÇÃO COMO PRÁTICA CRÍTICA: USANDO A RETRADUÇÃO NO ENSINO DA TRADUÇÃO}

Este artigo aborda a questão de como relacionar a teoria à prática no ensino da tradução. A retradução é vista como uma prática crítica (KYDD, 2011) que associa engajamento crítico a traduções concretas, e a teoria à prática. Essa reflexão crítica faz parte da competência tradutória, tanto na formulação minimalista de Pym (2003) como nas diretrizes do Mestrado Europeu em Tradução. Pode-se, portanto, considerar que a retradução ajuda os estudantes a alcançar o tipo de consciência crítica que integra a competência tradutória. O trabalho sugere uma série de atividades práticas de aprendizagem que se utilizam da retradução. Tais atividades vão de análises de retraduções do mesmo texto à realização de retraduções comentadas, em que os estudantes devem explicar os procedimentos adotados. Cada uma delas oferece maneiras de extrapolar a crítica textual, de modo a contemplar questões teóricas mais amplas.

Palavras-chave: Retradução; Pedagogia da tradução; Prática reflexiva; Competência tradutória; Elaboração de comentários

\section{TRANSLATION AS A CRITICAL PRACTICE: USING RETRANSLATION WHEN TEACHING TRANSLATION}

This article addresses the question of how to relate translation theory to translation practice when teaching translation. Retranslation is viewed as a critical practice (KYDD, 2011) that integrates critical engagement with existing translations and theory into practice. This critical reflexion is part of translation competence, both in Pym's (2003) minimalist formulation and the 
European Master's in Translation guidelines. Retranslation can therefore be seen to help students achieve the sort of critical awareness that is part and parcel of translation competence. A series of practical learning activities are suggested that use retranslation. These range from analyses of retranslation of the same text to commented retranslations that ask the students to explain their own process. Each of these offers ways of going beyond textual criticism to engage with wider theoretical concerns.

Keywords: Retranslation; Translation Pedagogy; Reflexive Practice; Translation Competence; Commentary Writing

\section{Elisa Figueira de Souza CORRÊA}

\section{FICÇÃO JAPONESA EM PROSA PUBLICADA NO BRASIL}

Resumo: Este texto serve de introdução aos dados resultantes de pesquisa exaustiva que procura identificar todas as diferentes obras de ficção japonesa em prosa publicadas no Brasil, em suas diversas edições, excetuando-se reimpressões, até 2020. Expõe-se a proposta da pesquisa, motivação, públicoalvo, metodologia e contribuição esperada. A parte dos dados apresenta, em dois quadros, as 171 edições encontradas, com comentários em notas de fim. A divisão em dois quadros separou obras de autoria única das coletâneas mistas, possibilitando exposição de todos os autores e tradutores. Quando possível, indica-se se a tradução foi feita diretamente do japonês ou não.

Palavras-chave: literatura japonesa; ficção japonesa; prosa japonesa; tradução japonês-português

\section{JAPANESE FICTION IN PROSE PUBLISHED IN BRAZIL}

This text is an introduction to data resulting from an exhaustive research that seeks to identify all the different works of Japanese fiction in prose published in Brazil, in their various editions, except for reprinting, up to 2020. It presents research proposal, motivation, target audience, methodology and expected contribution. The data part presents, in two tables, the 171 editions found, with comments in endnotes. The two tables separated works of single 
authorship from mixed collections, allowing to clarify all authors and translators. When it is possible, it is indicated if the translation was made directly from Japanese language or not.

Keywords: Japanese literature; Japanese fiction; Japanese prose; Japanese-Portuguese translation 